\title{
SOME BIOCHEMICAL ALTERATIONS ASSOCIATED WTTH CARBOHYDRATE DEFICIENCY IN PREGNANT GOATS, WTTH PARTICULAR REFERENCE TO PREGNANCY TOXAEMIA
}

\author{
Kamel, A. A. \\ Anlnal Health Research Irstilute. Zagazly
}

\begin{abstract}
SUMMARY
The goal of the present study uas to investigate some blochemical alterations in pregnant yoats suffering from carbahydrate deflekncy. The main clinical signs were allorexta depresston. locombion disturbankes from staggering gait to stemum recum. bancy which might have resulted in reduced entergy intake and precipitated pregurancy taxaemia. Blood and wine samples uxere collected from 12 diseosch animals before ard after treaiment trats. Sanytes were also collected from 8 late pregnarit goats that were proved healuy. Labaralory findings shougd ketorumia. lower serum ualues of glucose, chtolesteroh triglycerides and insulth. Higher serum liter eraymes, wran crealtnine, Lotal uplids, free faty acids. B-OHB and cortisol, were obsened. The response of the affected goats to conventonat therapeutic trealment was watible. It could be conchuded thext, the atisturbance in ration constituents especially carbolydiales leads to prcgnancy discase which can be prevented by the subsequent correction of carbolydrate and lipid paranebers in affected goats with butancing the mithitontal frlake of the goals with the increased late prognuncy needs of the dain and hor fetus to awold and prevent the accurrence of this syndrome.
\end{abstract}

\section{INTRODUCTION}

Carbuhydrate denctency results from a drop tn the plane of nutrtion durtrig last pregnancy and/or management changes that create a brief pertod of fasting leading to pregnancy disease (Kimberling, 1988). Undernourtshment or starvallon of multiple pregrant cwes resulted in Pregnancy ketosis (Reld, 1968 and Bergman, 1984). A falture of dietary energy and cnergy fiom gluconcogencsis to neet the increasing faetal glucose demands th the last 6 weeks of a mulluple pregnancy leads to pregnancy toxaernia (Sarglson, 1994). Thic detcrinining cause of coxacinla is an alteration In the encrgy metabollsin. as a conscquence of ard imbalance between glucose offer and dcunand, thereby glving rise to negative encrgy balance. This tmbalance is caused by a reduction In energy supply due to poor or Inadequate nutrition, In addition to the increasing re- 
qulrernents of the fetus in its last prenatal growth phise and the pressire of the gravid uterus ugion the digestive organs within the abdomlsal cavty (Kay and Baird, 1901 and Van Saun, 2000). The eonsumption of lav energy levels or poor utnization of the avallable energy sujply glves risc to a gradual reductlon in blood glueose levcls, with depletion of the llver glycogen reserves and moblitzation of the fatty depols for use as an urmsual encrgy source with the subsequent fonnation of ketone bodles and fatty liver inniltrallon (Radostlts et a.., 2000). 'The condition can bc dlagnosed by clinlcal examlnation of animals and confirmed blochemically by a marked increase in the concentration of $\beta$-hydroxybutyrate and a corresponding decease in the plasma gluonse concentratton (Scott and Woodman, 1993). "The present study atmed to investgate some blochemlcal alterations assoetated with carbohydrate dellciency in pregnant goats. wilh partlcular reference to pregnancy toxaemia.

\section{MATERLALS AND METHODS}

A total number of 40 late pregnant balady goals of 3-5 years old were obtalned from a private farm in Abo-Hammad, Sharkda Govemorate. The history of the flock Indicated that these anlmals were inadequately fed (rice straw. grass and sometimes concentrates). The elinical signs were anorexia. depression. locomotlon disturbances from staggering galt to sternum recumbancy of some cases which inight have resulted in reduced energy Intake and precipitated pregnancy toxaemia.

Blood and urine samples wcre collected from 12 clinically affected goats before and 7 days after trcatınent, Samples were also collectd from 8 late pregnant animals that were proved healthy after precise clinlcal and laboratory examlnattons. Blood samples were eolleeted from the Jugular vein In clean and dry centrifuge tubes for separation of serum to estimation of serum glucose (Caravay, 1978). enzyme activitles of aspartate aminotransferase (AST), alanine aminotransferase (Al.T) (Reitman and Frankel, 1957), alkaline phosphatase (ALP) (Tletz and skuey, 1986). blond urea nltroget (BUN) (Patton and Crouch, 1977), creatlnine (Henry, 1974), total lipids (Chabrol and Charonat, 1937). trigycerides (Trinder, 1969). total cholesterol (Watson, 1960). free fatty acids (Schuster and Pilz, 1979) and $\beta$-hydruxybutyrate ( $\beta$-OHB) (Mercer et al., 1986) by using dlagnostic reagent kits supplted by BloMerteux, Marey-L Etolle. France. The hormonal assay of cortisol and Insulin were done by using direct radiolmmunoassay technique with coat $A$ eount (DPC) kils according to Burtis et al. (1904). Urine samples were Immedtately used for detecllon or ketone bodies using eoumbour-9 test-strips (Boehringer Monnhelm, Germany).

A tulat of treatment almed to comect energy and stimulating appetite. where the diseased goats were recelved dally $1 / v$ injecton of $250 \mathrm{mll}$ of $25 \%$ dextrose lonce a dayl in addition to 10 
gm sodlum bicarbonate (once is day) and 250 ml Runger solution orally/head (twice a day) until goats eat normally,

The obtalned data were statustucally analyzed by using the analysis of varlance according to Snedecor and Cochran (1982).

\section{RESULTS}

Upon cllnical exansination, the affected goats were with varlable degrees of alfection ranged from dullness, depresslon. inappetauce and star gazing to stemum rccumbancy of sone cases. The smcll of acetone was detected in the breath. Results of the trial trealment showed that 6/12 or the affected goats showed elinlcal improwement and $4 / 12$ were partlally recovercd, whille 2/12 of the affected goats were died insplte of treatment.

Laboratory findings as shown in Table (1) have showcd a signuficant increase, (P<0.00 I) in Iiv. er enzymes activitues; AST, ALT and ALP and (PCO.01) in kldncy parameters (urca and ercalinine) in alfected goats compared to hicalthy ones.

Serum conccntrations of glucose. cholcsterol and triglycerides showcd a siguifleant dcercase (P<0.01) whlle total liphds were slgniflcantly tncreascd $(\mathrm{P}<0.01)$ in the discased group as compared to the coutrol ones. Serum Iree fatty acids and _-OHB values showed a slgnificant clevathon $(\mathrm{P} \times 0.001)$ In affected goats than hoalthy omes.

Cortisol level revealed a slguificant increase ( $\mathrm{P}<0.001$ ), whille Insultn level showed signifkant dccrease ( $\mathrm{F}<0.01)$ in the diseased goats as compared to the healthy ones.

Ketonc bodies wcre detected in the urine of affected goats indicallng ketonuria.

\section{DISCUSSION}

The affcctcd gonts had a history of insufficient fced supply especially carbohyctratc diet prior to the onset of ellnical discase. A qualitalively insufficlent feeding program together with the signilleant increased glucose consumption by the rapldly growing fotuses indure progredlent hypoglycemla and ketosis. Other factors like stress and decreased rumiual volunic may help triggerIng the netabolle breaktown of fat (Brus, 1989). Anorcxia, dcpression, duliness, loconotion disturbances from staggering gatt to stcrnum recumbency of some cases were signs observed in affected goats. These observations are in agrecment with El-Sebale et al. (1992). Nasger et al, (1998) and Mohamed et al. (2005). The clinical signs wcre confirmed by the presence of ketone. bodies in urine of the affected goals indicalng ketonurla. Once the encrigy Imbalance. in affected

Mansakra. Vet. Med. .r.

Vol. VII, Na. 1. 2006 
goats, has become established, the host systems attempt to malntain sufficlent blood glucose levels to satisfy the nceds of the mast vital tussues of the fetus. This done by liver gluconeogentsls from proplonate derved from carbohydrate digestion, amino acids and glycerol. When the avallabulty of proplonate proves insufficlent, gluconeogenesls makes use of body reserves in the form of fat and protelns via the sceretion of giucocorticoldes, thereby generating lange amount of acetyl coenzyme $\mathrm{A}$ (Brus, 1989).

Laboratory findings revealcd that the increase in the acturitses of serum cnzymes (AST, ALT \& AL.P) In diseased goals is an evdence for the degree of hepatic damage. These results wcre cotncided with that reported by E1-Sebade et al. (1992), Nasser et al. (1998) and Mohamed at. (2005). This is in accondanee with the fact that in the event of encrigy deficiency, the bxody uses Its fatty thssuc reserves as a source of energy. Thereby leading to important lipolysis, which in turn Increases the presence of circulating free fatty aclds that reach the liver and ind uce fatty inmitration with subsequent IIver degeneration (Brus, 1989 and Radostits et al.. 2000).

The elevated values of serum urea and creatinine in diseased goats can be explained by the observation of Parry and Tylor (1956) who lound ratty Inflitration in the tubular epithellum of the kJdneys of ketotic ewes. West (1996) and Makuyana et al. (2002) altrtbuted that increases to reduced glomerular flitration as result of extenslve degenerative changes of the kidneys.

The results obtained for serum glucose indicate that the dlseased goats were hypoglycemic. These results could be conflrmed with thase oblained by Storry and Rook (1982) and Jonsson and Pehrson (1972) who found that the glueasc levels are related to the animals energy status. values fulling with a negative energy balance. while Ford et al. (1990) and west (1996) attutbuted that to the diminished glucose supply from increasing fetal demand as pregnancy progresses and decreased glueose protuction due to undernourlshment. Schlumbohm and Harmeyer (2004) rccorded that high ketone body concentratlons suppress the endogenous production of glucose by approxhmately $30 \%$ and this raellitate the development of pregnancy toxaemsa in pregnant sheep.

Conceming the lipogram plcture, the results revealed significant $(P<0.01)$ reduction of cholesterol and triglycertdes levels and signincant (P<0.01) Increase of total liplds with significant (P<0,001) Increase of free fatty acids in diseased goats as compared with healthy ones. The reduction of the eholesterol and triglycerides levels is may be attributed to the reduction of glucose level that particlpate in the fonnation of glycerol and triglycertides. In addition the llver InfitraUon with large amount of free fatty acids with the subsequent development of latty liver have resulted in the inability of the lver to re-estertfy ratty actds into krtglycendes (Hay and Badrd, 1991; Radostite et al., 2000 and Latimer et al., 2003). On the other hand, the increase of 6 - 
tal lipids level is due to the moblization of free fatty actd from fat depots to be used as source of energy through Inereased Hpolysis and glyconeogenesis in a trial to compensate the reductuon of the glucose level (Brus 1889 and Hence et al., 1898). The sharp increase in the concentrations of free fatty acids in affected goats could be altributed to the Increased mobilization of fatly acids from the adipose Ussues in response to an Inereased requircment for cndogenous substrate for energy production during pregnancy (Noble et al., 1971), Russel et al. (1967) suggcstcd that plasma free latty acids would be the most useful Index of the degree of undernourishment in prognant ewes.

As shown in Fable (1). the (1-OHB revealed significan $(\mathrm{Y}<0,001)$ incrcase in affected goats as compared to the healthy ones. This observation is in aecordanee with Henze et al. (1898) in sheep and with sackran et al، (2004) In goats. Pregnaney disease is a condition which can be dfagnoscd by clinical examination of ewcs with signs of hepatie enceptialopithy whiels can be conflned btoehemieally by marked Inerease in serum eoncentration of $\beta$-hydroxybutyrate and a corresponding decrease in plasma glucose conecutratuon (Scott et al.. 1995).

Concernlng the serum corusal lcvel, it showed a marked incroase in discased animals when compared to healthy ones. Kimberling (1988) postulated that the stress and low caloric intake in pregnancy loxaemic antmals have a profound eflect on the kidney and adrenal gland whil a sigmificant reduction in renal blood how and glounerular filtration rate which ralsc plasma renin activilies and elevate plasma corusol levels. Another explanation. the tncrcase of serum cortisol levcl may be the consequence of increased glucocorteolds nutput in response to stress or reduced excretion hy the liver (Ford et al., 1990 and Henze et al., 1998),

Regarding the level of insulun hormone, It showed a signiflcant (P<0.01) decrease in the diseased goats. The drop of the insulin level may be a reflex of decreased glucose level for lacilitatIng the hepatic synthesls of glucose (Hart et al., 1978). In late pregnancy, pancreatic velease of Insulhy tend to decrease resulting in lower blood glucose level and stimulated synthesis of kelone bodies in the liver (Vernon et al., 1981 and Fernandex \& Lee. 1987).

Kimberling (1988) dcscrbed that the toral feed requirements for the slingle bearing ewc flurIng the last 6 weeks is $1.5 \times$ maintenance and $2 \times$ maintenance for a twin beaning ewe. The additional energy for this perind is best supplied by coneentrate fecds as the rumcn capacily is linnied by letal expansion. Accordingly the animals included in this study recelve low feed requirements (rtce straw, grass and less concentrates) which led to the accurrence of this eondition.

1t could be conclnded that, the disturbance in ration constuluents cspectally carbuhydrates leads to pregnancy discase which can be prevented by the subsequent roneetion of carbolny- 
drate and lypld parameters in affected grats with balancing the nulritional Intake of the goats with the inereased late pregnancy needs of the dam and her letus to avold and prevent the occurrence of thls syndrorre.

\section{ACENOWLEDGEMENTS}

The author is grateful to Dr. Hoda, M.L. Abd Alla, Senior Researeher, Anlmal Health Research Instltute-Zagazig, for her supervision of the blood collection and expert technical assistance. 
Table (1): Some laboratory findings in both apparently healthy and diseased goats before and after therapeutic treatment (mean \pm S.E).

\begin{tabular}{|c|c|c|c|}
\hline \multirow{2}{*}{ Parameter } & \multirow{2}{*}{$\begin{array}{l}\text { Healthy goats } \\
(n=8)\end{array}$} & \multicolumn{2}{|c|}{ Diseased goats $(n=12)$} \\
\hline & & Before trentment & After treatmient \\
\hline$(\mathrm{U} / \mathrm{L})$ & $48.75 \pm 1.55$ & $60.08 \pm 2.16^{* * *}$ & $55.83 \pm 2.54^{*}$ \\
\hline$(\mathrm{U} / \mathrm{L})$ & $23 . \overline{62 \pm 0.75}$ & $32.25 \pm 1.56^{* * *}$ & $26.58 \pm 0.89^{*}$ \\
\hline$(\mathrm{U} / \mathrm{L})$ & $41 . \overline{37 \pm 1.70}$ & $53.75 \pm 1.84 * * *$ & $47.91 \pm 2.20^{*}$ \\
\hline$(\mathrm{mg} / \mathrm{di})$ & $27.63 \pm 1.16$ & $35.41 \pm 1.72^{* *}$ & $29.75 \pm 1.23$ \\
\hline Creatinine & $1.41+0.12$ & $1.9510 .12^{* *}$ & $1.57 \pm 0.10$ \\
\hline Glucose & $53.87 \pm 2.54$ & $42.75+2.29^{* *}$ & $49.83 \pm 2.12$ \\
\hline Cholesterol (mg/dI) & $67.50 \pm 2.06$ & $53.91 \pm 3.20^{* *}$ & $62.41 \pm 2,25$ \\
\hline Triglycerides (mg/di) & $53.62+3.02$ & $38.33 \pm 2.94^{* 4}$ & $48.08 \pm 2.18$ \\
\hline Total lipids $(\mathrm{mg} / \mathrm{dl})$ & $318.75 \pm 12.11$ & $389.91 \pm 17.62^{* * *}$ & $346.25 \pm 14.01$ \\
\hline Free fally acids (mg/dl) & $21.62 \pm 1.66$ & $36.50 \pm 2.24^{* * *}$ & $27.41 \pm 1.75^{*}$ \\
\hline$-\mathrm{OHB} \quad(\mathrm{mg} / \mathrm{dl})$ & $6.37 \pm 0.73$ & $11.83 \pm 1.06^{* * *}$ & $8.91 \pm 0.95^{*}$ \\
\hline Cortisol & $15.12 \pm 1.06$ & $30.33 \pm 2.76^{*} *$ & $20.16 \pm 1.59^{*}$ \\
\hline (ng/dl) & $7.62 \pm 0.65$ & $5.01 \pm 0.24 * *$ & $6.80 \pm 0.21$ \\
\hline
\end{tabular}

$* \mathrm{P}<0.05 \quad * * \mathrm{P}<0.01 \quad * * * \mathrm{P}<0.001$ 


\section{REFERENCES}

Bergman, E. N. (1984) : Disorders of earbohydrate and lat inctabolisni in: SWENSON. M.J. [ed.). Duke's Physlology of domestic animals, Comell Untverslly Press. Ithaka, N.Y. and London.

Brus. M. L. (1989) ; "Ketogenesls and Ketosts". In : Clinical Blochemistry of Donnestic Auimals. J.J. Kancko. 4th Ed, Aeademie Pross, San Diego, P. 86-105.

Burtí, C. A. Ashwood, E. R. and Saunders, W. R. (1994) : National Committee for Clinical Laboratory Standards, 3rd Ed. N.C.C.I.S. Document H3-A3, editors Thetz Textbook of Clinlcal Chemistry, 2nd Ed. Philadelphla.

Caraway, w. T. (1976) : Quantitative enzymatte colorimetre determination of ghucose in senum. plasma or C.S.F., Fundamentals of Clnical Chcmistry. 2nd E.d. W.B. Saunders, Philadelphda.

Chabrol, E. and Charomnat, R. (1937) : Colorimetric determination of tolal liplds. Press Med. 96: 1713

E1-Sebale, A. H.; El-Shazely, M. A.; El-Gharram, M. and Alhindt. A. B. (1992) : Pregnancy toxaemla In goats and sheep: Clinlcal updating. Proc. 5th Sel. Cong. Fac. Vet. Med. Assiul Unlv., 1: 9-18.

Fermandex, J. M. and Lee, D. B. (1987) : Metaholic disorders in goats: Pregnancy Loxaemia. Proc. 2nd Annual Field Day of the Anner. Insutute for Goat Research. 141-158.

Ford, E. J. H.; Evans, J. and Robinson, O, J. (1900) : Corlisol in pregnancy taxaemla of shcep. Brit. Vet. J., 146: 539-542.

Hart, I. C.; Bines, J. A.; Morant, 8. V. and Rldly, J, L. (1978) : Fndocrine control of energy in the cow. Comparison of the levels of hormones and metabolltes in the plasma of high and low ylelding eatle at varlous stages or lactation. J. Endocri., 77: 333-350.

Hay, L. A and Balrd, G. D. (1991) : Pregnancy toxacmla. In: Discases or streep. 2nd Ed. P. 254257. Blarkwell Scicntile Publleations, Oxford.

Henry, R, J. (1974) : Determination of scrum creatlnine. Clinieal Chemtstry. Principles and Techniques. 2nd Ed. Harpers and Row, P. 525.

Henze, P.; Blckhardt. K.; Fuhrmann, H. and Sallmann, H. P. (1998) : Spontanesus pregnan. cy toxaemla (Ketasts) in sheep and the role of insulln. J. Vet. Med. A 45. 255.266.

Jonsmon, G. and Pebrzon, B. (1872) : Some blood parameters In dalry cows al diflcrent feeding Intensitles. Internatlonal meeting on diseases of cattlc, London, 250-257. 
Ktmberling. C. V. (1988) : Jenseit and Swifs Dlseases of sheep. 3rd Ld. Lea \& Febiger Ithladclphas.

Latimer, K. 8.; Mahaffey, E. A. and Prasse, K. W. (2003) : Protein, lipid and carbohydrales. In: Veterinary Laboratory Medicine. Clinical Pathology. Dunean and Prasses 4th Ed. lowa State Press. P. $171-178$.

Makuyana, D.; Mahomed, K.; Shukusho, F. D. and Majoko, F. (2002) : I, ver and kidncy functlon in nomal and pre-edamptic gestation. A comparison with non-gestatlonal referurice values. Cent. Afr. J.Med., 55-59.

Mercer, D. W.: Losos. F. J. and Mason. L. (1986): Monttoring therapy with saline in ketoacidotic patients by quantifying $\beta$-hydroxybutyrate with a eommercial kils. Clin. Chem., 32: $225-228$.

Mohamed, A.M.: Ratcb, H.Z.; Abd Ellah, M.R. and Amer, A.A. (2005): Renal ard liver testIndlecs under spontaneous cases of pregnancy toxaemia in goats with special reference to therapeulse trals. Assiul Vet. Med. J.. 51 (106). 84-91.

Nasser, M.H.; Dawlat, M. Amin; Mousa, Sh.M; Omima, M. Kandial; Fatma, M. Kamel and Agag, B.1. (1998): Piegnancy Laxaemia in shcep and goals (Clinical and binchemical aspec(s). Assiut Vet. Med. I. 38 (76) : 138 - 150.

Noble, R.C.: Steel, W. and Moore, J.H. (1971): The plasma liplds of the ewe during pregrancy coxaemia and laclation. Res. Vet. Scl., $12: 47-53$.

Parry, H.B. and Tylor, W.h. (1958); Fenal functions in shecp durng nonmal and loxacinic pregnancy. J. Physiol., 131: 383-392.

Patton, C.J. and Crouch, S.R. (1977); Colorimetric detennination of blood urea nitrogen. Anal. Chem, 49: 464-469.

Radoatits. O.M.; Gay, C.C.; Blood, D.C. and Hincheliff, K.W. (2000): Kelosis of Ruminants. In; Veterinary Medichic. 9 th Ed, W.B. Saunders Co. LLd., London, New York, Philadelphia and Toronto. P. 1343.1354.

Reld, R.L. (1968): The plysslopathology of undernourishment in pregnant sheep. with particular relerence to pregnancy toxacmla. Adv. Vet. Set. 12: 163-228.

Reltman, s. and Frankel, s. (1957): Colorimeluic deterinination of GO' and GPI activities. Auntr. J. Clin. Path. $28,56$.

Russel, A.J.F.; Doney, J.M. and Reid, R.L. (1967): 'The use of biochemical paramecers in con. trolling dutritional state in pregirant ewes and dic effect of undernourlshment during pregnancy on lairbs hirth-wcight. J. Agric. Sri. (Combridgel. 68: 359.

Mansoura, Vet. Med. J.

Vol. VII, No. 1, 2006 
Sackran, M.N.S; Ahdel-Axtz. M.Z. and El-Bakhmy. AS.M. (2004): Some clinieopathological and hormonad studies on pregriancy toxactnia in goats (A held sludy), Zag. Vet. J.. 32 (1): $168 \sim 178$.

Sarglson, N.D.; Scott. P.R.; Penay, C.D.; PHrle, R.S, and Kelly, J.N. (1994): Plasma enzymes and metabolites as potential prognostle indices of owne pregnancy toxaemla-a preliminary study. Br. Vet. J., 150: $271-276$.

Schlumbohm, C. and Harmeyer, J. (2004): Hyperketonemla Impalrs glucose metabollsm in pregnant and non-pregnant ewes. Dairy Sct, 87 (2): $350-358$.

Schuster, V.H.G. and PLy, V.K. (1979): Kolormerdsche Mikromethode Zur Bcsummung der Unveresterten Langkettugen Fettsauren Im Serum. Z. Med, Labor. Dlagn. 20: 212-217.

Scott. P.R. and Woodman, M.P. (1993): An outbreak of pregrancy toxaemla in a flock of ScotUsh Blackface sheep. Vet. Rec., 133: 597-598.

Scott, P.R.; Sargison, N.A. Penny, C.D.; P(rte, R.S. and Kelly, J.M. (1905): Ccrebrospinal fluld and plasma glucosc concentrations of owne pregnancy toxaemik cascs. inappetant ewes and nornal ewes duning late gestatlon. Br. Vet. J., 15I: 39-44.

Snedecor, G.W. and Cochran, W.G. (1982): Statistical Methods. 8th Ed., Towa State Univ. Press, Anncs lowa. U.S.A.

Storry, J.E, and Rook, A.F. (1962): The effect of level of reeding before and after calving on the concentration of plasma glucase in the cow. Proc. Nutr. Soc., 21:39-40.

Tietz, N.W. and shuey. D.F. (1986): Colorimetric determination of serum alkaltre phosphatasc. Clin. Chem., 32: 1593-1594.

Trinder, P. (1969): Eirxymatic colormetric determination of triglycerlde in serum or plasma. Ann. Clin. Blochem., 6: 24-27.

Van Saun, R.J. (2000): Pregnancy toxaemia in a flock of sheep. J. Am. Vet. Med. Ass., 217 (10): 1536-1539.

Vernon, R.G.i Clegg, R.A and Fint, D.J. (1981); Metabolism of sheep adlposc Ussue during pregnancy and lactation. Adaptatlon and regulation. Blochem. J., 200: 304-314.

Watson. D. (1960): A simple methods for deternination of serum cholesteral. Clln. Cheni. Acta, 5: 637-641.

West. H.J. (1996): Material under nutrtion during late pregnancy in sheep. Its rclation to matemal condition, gestation length, hepatte physlology and glueose metabolism. Br. J. Nutr., 4; 593-605.

Mansoura, Vet. Med. J.

Vol, VII, Na. 1, 2006 


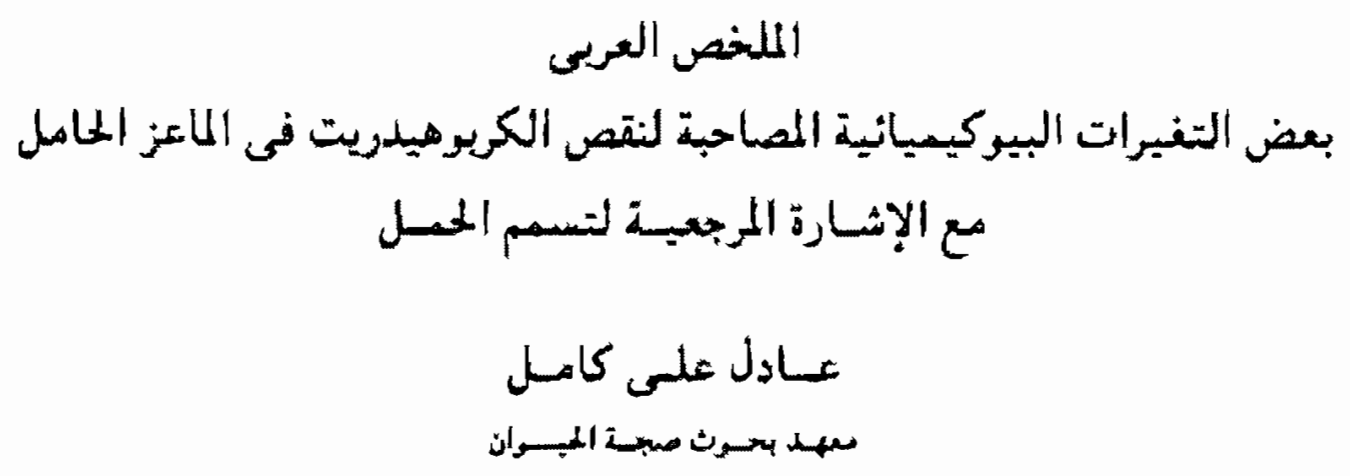

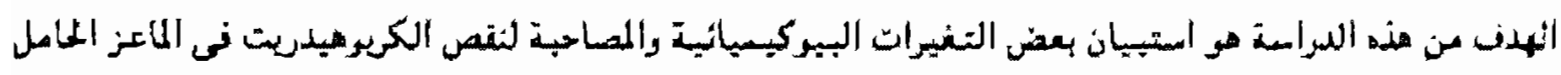

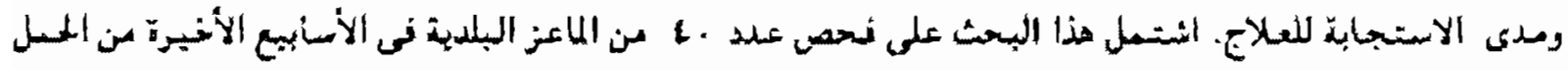

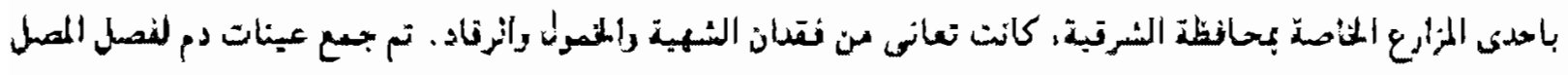

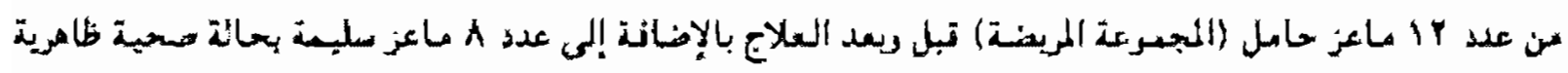
جيدة (الجعرعة المبايطة)

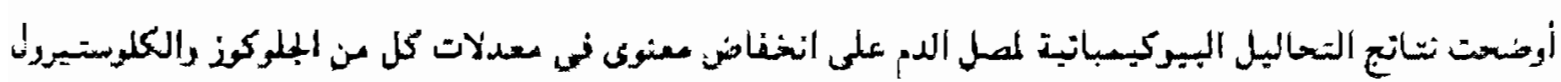

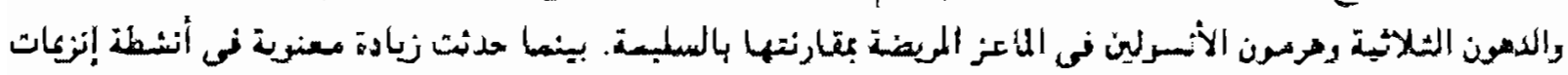

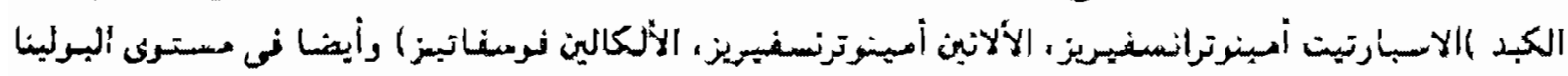

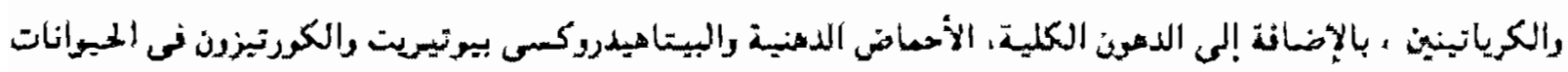

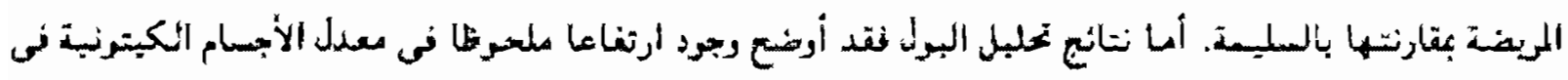

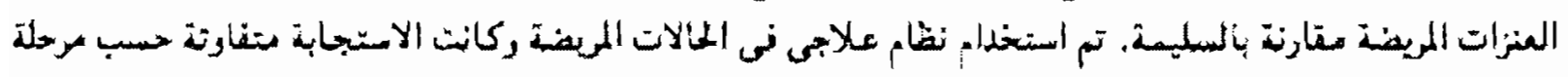

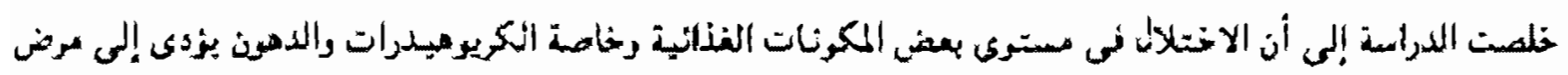

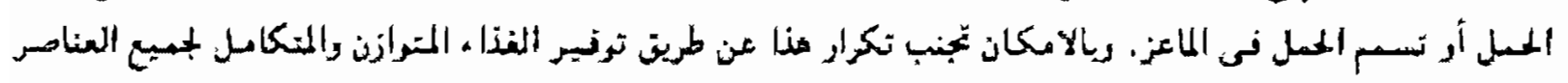

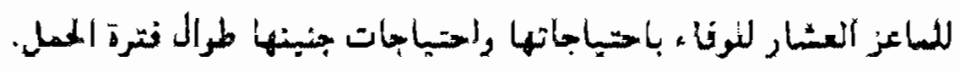

